Polymer Journal, Vol. 39, No. 6, pp. 514-523 (2007)

(C) 2007 The Society of Polymer Science, Japan

\title{
Influence of Filler Types and Contents on Foaming Structures in ABS Microcellular Foams
}

\author{
Atsushi Tsuchiya, ${ }^{1,3, \dagger}$ Hirofumi Tateyama, ${ }^{1}$ Tokio KIKUCHI, ${ }^{2}$ \\ Tatsuhiro TAKAHASHI, ${ }^{3}$ and Kiyohito KOYAMA ${ }^{3}$ \\ ${ }^{1}$ R\&D center, Munekata Co., Ltd., Hourai-cho 1-11-1, Fukushima, 960-8506, Japan \\ ${ }^{2}$ Material Technology Group, Fukushima Technology Centre, Machiikedai 1-12, Koriyama, 963-0215, Japan \\ ${ }^{3}$ Department of Polymer Science and Engineering, Yamagata University, Jonan 4-3-16, Yonezawa, 992-8510, Japan
}

(Received November 20, 2006; Accepted March 2, 2007; Published April 27, 2007)

\begin{abstract}
The influence of filler types and concentration on the foaming structure was investigated using a batch method to penetrate $\mathrm{CO}_{2}$ in ABS polymer matrix. Vapor grown carbon fiber $\left(\mathrm{VGCF}^{\circledR}\right.$, averaged diameter $=$ $150 \mathrm{~nm}$ ), and calcium carbonate (averaged particle diameter $=1.8 \mu \mathrm{m}$ ) were used as fillers and the concentration was changed from 5 to $15 \mathrm{wt} \%$, respectively. Vapor grown carbon fiber or calcium carbonate was compounded with ABS using an extruder and samples were made by hot press method. Foamed samples, whose density reduction showed about $30-40 \%$, were made by controlling preparation conditions.

In the case of vapor grown carbon fiber/ABS systems, the average diameter of foaming cell decreased, and the cell density increased as a function of fiber concentration. On the other hand, by the incorporation of calcium carbonate, the diameter increased, and density decreased with higher concentration. The initial nucleation stages of foaming from fillers were carefully observed for fillers having large aspect ratio and particle shape. Based on the evidences from optical microscope observation, the different tendency of cell diameter between the two systems as a function of concentration was discussed. [doi:10.1295/polymj.PJ2006168]

KEY WORDS Microcellular Plastic / ABS Resin / Vapor Grown Carbon Fiber / Calcium Carbonate / Filler Content / Foaming Cell Diameter / Cell Density /
\end{abstract}

Recently the foam molding using a supercritical fluid has been receiving remarkable attention. The foams molded by this method exhibit cell diameter having less than 10 micrometer, and cell number density having greater than $10^{9}$ cells $/ \mathrm{cm}^{3}$, thus usually called as microcellular foams, compared with the conventional foaming technology using chemical blowing agents. Because of their microcellular foaming structure, it is known that microcellular foams show no strength decrease or less strength decrease even through foaming, which has been disadvantage of conventional foams. ${ }^{1-4}$

However, it is not easy to mold microcellular foams in extrusion foam molding, blow foam molding, and, especially, injection foam molding, because the molding process is complex. So, the research and development about foam molding process has been carried out in various places such as industry, governmental research institution, and university. ${ }^{5-7}$ It is known that foaming structures were changed greatly by types of resins and its viscosity during the foam molding using a supercritical fluid. ${ }^{8,9}$ Especially, when using resins containing fillers, foaming cell structure becomes smaller compared with that without fillers. For example, in the batch foam method, it is reported that foaming cell diameter decreases and cell density increases by adding the clay (a nano scale size filler) or glass beads (a particle diameter of 2 micrometers) to olefin resin. ${ }^{10,11}$ While in the extrusion foam molding, it is reported that the coefficient of cubic expansion of the foam decreases and the cell density increases by adding talc to olefin resin or styrene resin. ${ }^{12,13}$

As described above, foaming structure changes greatly with containing fillers in resin. Therefore, it is important to clarify the effect of filler shape and its content on foaming structure and its foaming mechanism. However, the foaming mechanism of resin containing filler has been unknown up to now due to no microscope observation evidences.

In this study, we have compounded and molded ABS resin with two fillers, fiber type and particle type fillers, and made foamed sample using a batch foam method. We have controlled foaming conditions such as temperature and time, so that we could obtain foamed samples having density reduction having $30-40 \%$. The influence of filler types and contents on the structure of microcellular foams was examined.

\section{EXPERIMENTAL}

\section{Materials}

ABS resin (DPS60, general grade, manufactured by

${ }^{\dagger}$ To whom correspondence should be addressed (Tel: +81-24-547-2617, Fax: +81-24-547-2629, E-mail: atsuchiya_trd@ munekata.co.jp). 
Influence of Filler Types and Contents on Foaming Structures in ABS Microcellular Foams

Table I. Used fillers in this study and their abbreviations

\begin{tabular}{|c|c|c|c|c|}
\hline Filler name & Manufacture & $\begin{array}{c}\text { Shape of } \\
\text { filler }\end{array}$ & Grade & Details \\
\hline VG-CF & $\begin{array}{l}\text { Showa denko } \\
\text { K. K. }\end{array}$ & Fiber & $\mathrm{VGCF}^{\circledR}$ & $\begin{array}{l}\text { Vapor grown carbon fiber, } \\
\text { Average diameter of fiber is } \\
150 \mathrm{~nm}, \mathrm{~L} / \mathrm{D}=10 \sim 500 \text {, Average } \\
\mathrm{L} / \mathrm{D} \text { of fiber is about } 26^{15,16}\end{array}$ \\
\hline $\mathrm{CaCO}_{3}$ & $\begin{array}{l}\text { Shiraishi } \\
\text { calcium Co., } \\
\text { Ltd. }\end{array}$ & Particles & $\begin{array}{l}\text { Whiteron } \\
\text { SB(red) }\end{array}$ & $\begin{array}{l}\text { Calcium carbonate, Average } \\
\text { diameter of particles is } 1.6 \mu \mathrm{m}\end{array}$ \\
\hline
\end{tabular}

Table II. Compositions investigated in this study and their abbreviations

\begin{tabular}{lcccc}
\hline $\begin{array}{c}\text { Sample } \\
\text { name }\end{array}$ & $\begin{array}{c}\text { Base } \\
\text { resin }\end{array}$ & $\begin{array}{c}\text { Contained } \\
\text { filler name }\end{array}$ & $\begin{array}{c}\text { Filler contents } \\
\text { (wt } \%)\end{array}$ & $\begin{array}{c}\text { MFR } \\
\text { (g/10 min) }\end{array}$ \\
\hline ABS & DPS60 & - & - & 44.2 \\
ABS/V5 & DPS60 & VG-CF & 5.85 & 38.3 \\
ABS/V10 & DPS60 & VG-CF & 9.54 & 30.1 \\
ABS/V15 & DPS60 & VG-CF & 13.72 & 26.9 \\
ABS/C5 & DPS60 & $\mathrm{CaCO}_{3}$ & 5.92 & 46.8 \\
ABS/C10 & DPS60 & $\mathrm{CaCO}_{3}$ & 11.11 & 46.9 \\
ABS/C15 & DPS60 & $\mathrm{CaCO}_{3}$ & 17.08 & 47.0 \\
\hline
\end{tabular}

Daicel polymer corporation limited, Japan) was used as the base resin. Fillers summarized in Table I were compounded into ABS resin using a twin screw extruder (KZW15-45 MG-FKS, manufactured by TECNOVEL, Inc., Japan). In order to mold microcellular foam, VG-CF was selected as a fiber type filler, while $\mathrm{CaCO}_{3}$ was used as a particle type filler. Special surface treatment was not performed and the fillers were used as received. The fillers were compounded into ABS. Filler concentrations of blended condition before extrusion were $5,10,15 \mathrm{wt} \%$, respectively. The actual content of the filler was measured by removing ABS resin with heating to $600^{\circ} \mathrm{C}$. The values of MFR listed in Table II were measured at $220^{\circ} \mathrm{C}$ with $98 \mathrm{~N}$ force based on JIS K7210. The dispersions degree of each filler in ABS resin was evaluated from SEM analysis at the cross-section of the hot-press molding sample.

\section{Foaming Condition}

The foaming conditions were summarized in Table III. Compound resins were molded in the shape shown in Figure 1 using the hot press machine (MP-2F, manufactured by Toyo Seiki Seisaku-sho, Ltd., Japan). The molded sample was thrown into high-pressure vessel. Then, carbon dioxide having 4.5 $\mathrm{MPa}$ of pressure was injected into the vessel at room temperature. Carbon dioxide was penetrated into a sample at room temperature $\left(24^{\circ} \mathrm{C}\right)$ for $24 \mathrm{~h}$ or more. With this treatment, the concentration of carbon dioxide in each sample reached each saturated region
Table III. Molding conditions of foaming samples

\begin{tabular}{ll}
\hline Hot press temperature & $200^{\circ} \mathrm{C}$ \\
Used gas & Carbon dioxide \\
Saturated temperature & Room \\
& temperature $\left(24{ }^{\circ} \mathrm{C}\right)$ \\
Saturated pressure of carbon dioxide & $4.5 \mathrm{MPa}$ \\
Saturated time of carbon dioxide & Above 24 hour \\
Foaming temperature in oil bath & $60^{\circ} \mathrm{C}$ \\
Foaming time in oil bath & $60 \mathrm{sec}$ \\
Used fluid in cooling process & Water \\
Cooling time in water bath & Above 24 hour \\
\hline
\end{tabular}

(illustrated in Figure 1), which was confirmed by the weight increase as a function of time. The increased weight percentage was found to be about 11 to $13 \%$. Each sample including saturated concentration of carbon dioxide was put into a oil bath with temperature control at $60^{\circ} \mathrm{C}$ for $60 \mathrm{~s}$. Each sample was foamed during heating. The density reduction of the molded sample by this heat treatment was about 30 to $40 \%$, and foaming structure gave many closed cells by SEM. Then, each sample was cooled immediately with water for $24 \mathrm{~h}$ to freeze cell structures, and carbon dioxide which was dissolved superfluously was gradually released from foaming sample. The foaming sample was dried at $80^{\circ} \mathrm{C}$ for $24 \mathrm{~h}$ using the vacuum oven (CV-232P, manufactured by Espec Ltd. Japan).

\section{Characterization}

Foaming structure was evaluated by calculating the density reduction of a foaming sample, the foaming cell diameter and its distribution, the average of foaming cell diameter, and foaming cell density. Density reduction was calculated from the density of the sample. The density of the sample was measured using the electronic hydrometer (MD-200S, manufactured by Mirage trade Ltd., Japan). The density reduction was defined by eq 1 :

$$
L=\left(1-\frac{\rho_{\mathrm{f}}}{\rho}\right) \times 100
$$

where, $L(\%)$ is the density reduction of the sample, and $\rho\left(\mathrm{g} / \mathrm{cm}^{3}\right)$ is the sample density before foaming, 


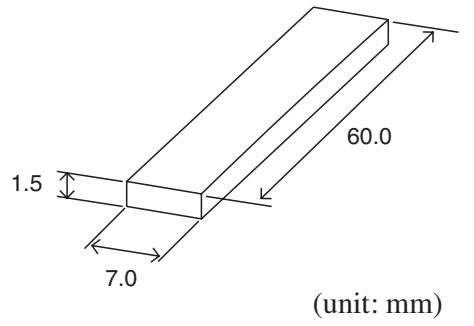

(a) Shape of sample molded by hot press

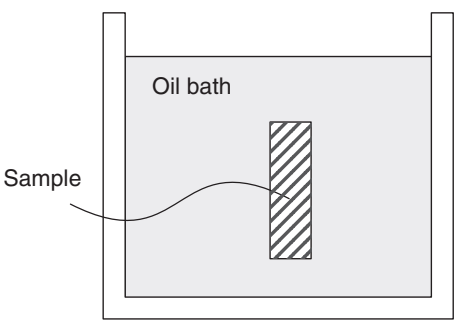

(c) Foaming sample

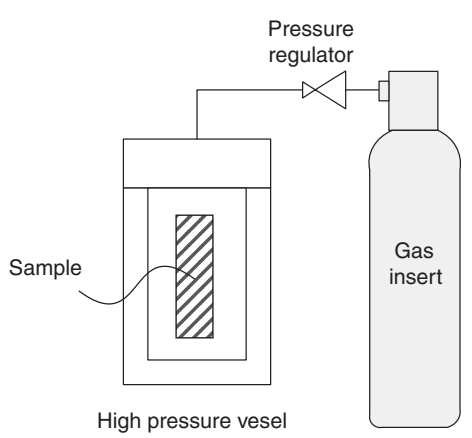

(b) $\mathrm{CO}_{2}$ saturation

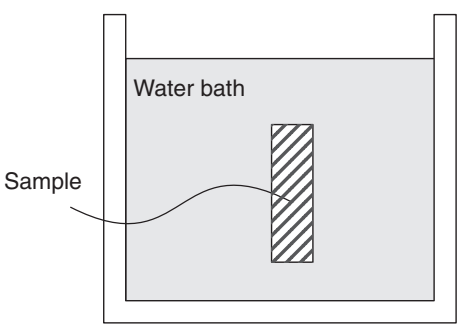

(d) Cooling sample

Figure 1. Molding and foaming process for various samples.

and $\rho_{\mathrm{f}}\left(\mathrm{g} / \mathrm{cm}^{3}\right)$ is the sample density after foaming.

The core layer of the cross-section of a foaming sample was observed using SEM (scanning electron microscope, manufactured by JEOL Co., Ltd., JSMT20, Japan). In order to evaluate foaming structure quantitatively, image analysis of the SEM photograph was carried out, and 200 or more foaming cells were selected for characterization.

The frequency distribution and the average of the foaming cell diameter were measured using imageanalysis software (manufactured by Mountech Co., Ltd. Macview, version 4, Japan). The foaming cell average diameter was calculated from frequency distribution. The foaming cell density was calculated by eq $2: 1$

$$
N=6\left(\frac{\rho}{\rho_{\mathrm{f}}}-1\right) / \pi D^{3}
$$

where, $N$ is the foaming cell density of the sample, and $\rho\left(\mathrm{g} / \mathrm{cm}^{3}\right)$ is the sample density before foaming, and $\rho_{\mathrm{f}}\left(\mathrm{g} / \mathrm{cm}^{3}\right)$ is the sample density after foaming, and $D$ is the foaming cell average diameter.

\section{Optical Microscope Observation}

In order to clarify the foaming behavior of initial foaming process in filler-dispersed resins, the effect of filler shape on the foaming structure was examined using other model systems including $0.01 \mathrm{wt} \%$ of filler. Carbon fiber (manufactured by Toray Industries, Inc., T-300, Japan) with fiber diameter of $8 \mu \mathrm{m}$ and $\mathrm{CaCO}_{3}$ (manufactured by Sankyo fine powder limited company, NS-2300, Japan) with averaged diameter of $50 \mu \mathrm{m}$ were used as model fillers, which are easily observed by optical microscope. These fillers were compounded to transparent ABS (manufactured by DENKI KAGAKU KOGYO Co., Ltd., CL-301, Japan), to obtain almost transparent samples including a trace amount of fillers. The sample (thickness $1 \mathrm{~mm}$ ) for optical microscope observation was molded using hot press. Carbon dioxide having pressure of $7 \mathrm{MPa}$ was penetrated to sample for 20 minutes in $40^{\circ} \mathrm{C}$. After taking out the sample, the carbon dioxide which was dissolved in the sample was slightly released to the atmosphere. Then, the sample was heated at $200^{\circ} \mathrm{C}$, and foaming was allowed to occur very slightly and it cooled. The cooled sample was observed, using optical microscope.

\section{RESULTS AND DISCUSSION}

\section{Density Reduction of Foaming Samples}

Figure 2 shows the density reduction of each foaming sample as a function of the filler content. The density reduction of all the samples was between 34 and $39 \%$, having slight decreased tendency with higher content. It is important to analyze how much percentage of penetrated carbon dioxide was lost during cell generation.

In order to get insight by chasing the penetrated carbon dioxide, Table IV summarized the weight change in the batch foaming process of typical sample along with process. The amount of absorbed the carbon 


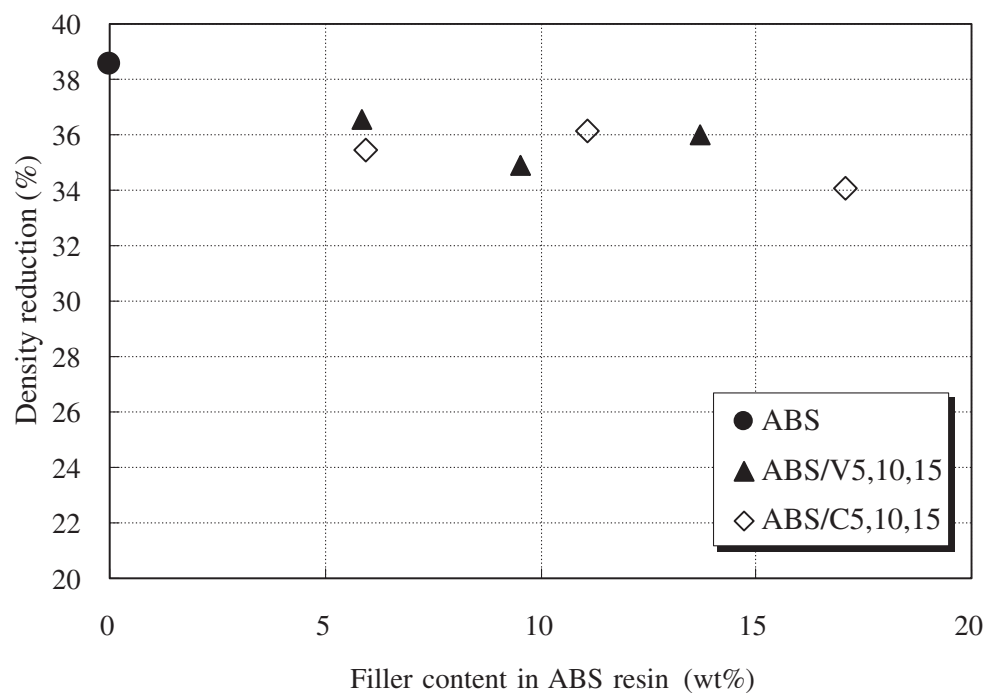

Figure 2. Result of density reduction for various samples.

Table IV. Weight change of each sample in the batch foaming process

\begin{tabular}{lccc}
\hline \multicolumn{1}{c}{ Sample name } & ABS & ABS/V10 & ABS $/ \mathrm{C} 10$ \\
\hline $\begin{array}{l}\text { Sample weight }(\mathrm{g}) \text { before } \\
\text { penetrate carbon dioxide }\end{array}$ & 0.659 & 0.729 & 0.731 \\
$\begin{array}{l}\text { Sample weight }(\mathrm{g}) \text { after } \\
\text { penetrate carbon dioxide }\end{array}$ & 0.747 & 0.812 & 0.816 \\
$\begin{array}{l}\text { Weight percent (wt } \% \text { ) of } \\
\text { penetrated carbon dioxide } \\
\text { calculated from weight change }\end{array}$ & 13.4 & 11.2 & 11.7 \\
$\begin{array}{l}\text { Sample weight }(\mathrm{g}) \text { just after } \\
\text { foaming }\end{array}$ & 0.732 & 0.793 & 0.792 \\
$\begin{array}{l}\text { Weight (g) of the lost carbon } \\
\text { dioxide by foaming }\end{array}$ & 0.015 & 0.019 & 0.024 \\
$\begin{array}{l}\text { Sample weight }(\mathrm{g}) \text { after } 24 \mathrm{~h} \\
\text { since cooling }\end{array}$ & 0.673 & 0.741 & 0.745 \\
\hline
\end{tabular}

dioxide in ABS resin was $13.4 \%$ (saturated concentration). On the other hand, those in ABS/V10 and ABS/ C10 were $11.2 \%$ and $11.7 \%$, respectively. By adding the filler to ABS, the percentage of resin matrix should decrease, resulting in the density reduction decreases (from 13.4 to 11.2 or 11.7). The difference about the decrease of density reduction between VG-CF and $\mathrm{CaCO}_{3}$ was hardly observed. It was confirmed that volume expansion ratio by foaming is same in the sample with the same filler content.

\section{SEM Observation of the Cross-Section}

Figure 3 shows a series of SEM photographs (the cross-section) of each foaming sample. Many small cells with size of $10 \mu \mathrm{m}$ or less were observed in the cross-section of ABS. Moreover, bigger cells than $10 \mu \mathrm{m}$ were not observed. The foaming structure of the foaming sample of ABS was micron-size. How- ever, foaming cell diameter of ABS/V5 became smaller compared with that of ABS. It has confirmed that the distribution degree of cell size seemed to become narrow (Figure 3b). Furthermore, by the increase in the content of VG-CF, the foaming cell diameter became much smaller (Figure $3 \mathrm{c}$, d). In addition, the distribution of foaming cell size also seemed to become smaller.

On the other hand, in the foaming structure of ABS/C5, many large foaming cells of $10 \mu \mathrm{m}$ or more were observed, compared with that of $\mathrm{ABS}$ (Figure 3e). By the increase in the content of $\mathrm{CaCO}_{3}$, the cell diameter obviously became larger and the distribution of size also became broader (Figure 3f, g, h).

\section{Evaluation Using Image-Analysis}

For quantitative characterization, image analysis of cells in Figure 3 was carried out, and cell diameter and its distribution was evaluated. The cell size distributions of ABS, ABS/V5, ABS/V10, and ABS/V15 were shown in Figure 4a. The distribution of foaming cell diameter in ABS, including butadiene rubber with a mean particle diameter of $0.3 \mu \mathrm{m}$, was $0.13-$ $3.65 \mu \mathrm{m}$, and the average diameter was $0.67 \mu \mathrm{m}$. The foaming cell density was $3.21 \times 10^{12}$ (cells $\left./ \mathrm{cm}^{3}\right)$, and it was a fine microcellular structure. By adding VG-CF (fiber diameter of $0.15 \mu \mathrm{m}$ ) to ABS, the frequency of $0.5 \mu \mathrm{m}$ or less increased in the particle size distribution of the foaming cell, and the frequency of $0.6 \mu \mathrm{m}$ or more decreased. The frequency which increased most was around $0.3 \mu \mathrm{m}$. By increasing the content of VG-CF, it was turned out that the degree of cell distribution becomes narrower.

Those of $\mathrm{ABS} / \mathrm{C} 5, \mathrm{ABS} / \mathrm{C} 10$, and $\mathrm{ABS} / \mathrm{C} 15$ were shown in Figure $4 \mathrm{~b}$. By adding $\mathrm{CaCO}_{3}$ (mean particle diameter is $1.8 \mu \mathrm{m}$ ) to $\mathrm{ABS}$, the frequency of $1-2 \mu \mathrm{m}$ 


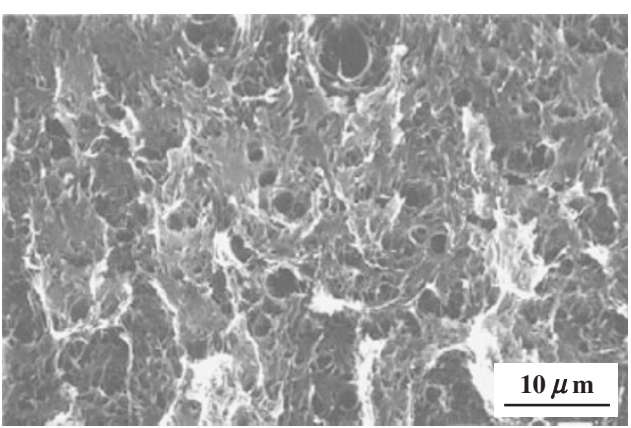

(a) ABS

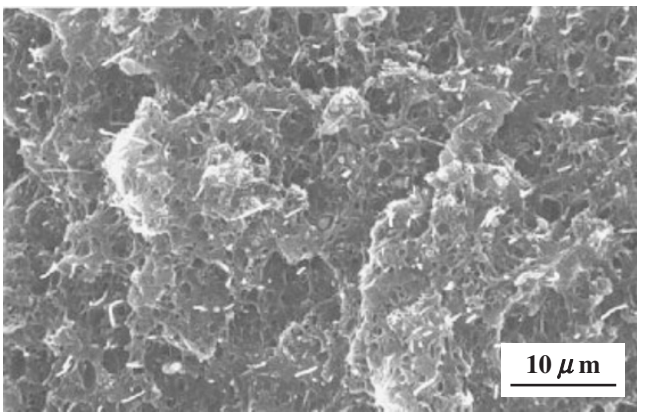

(b) $\mathrm{ABS} / \mathrm{V} 5$

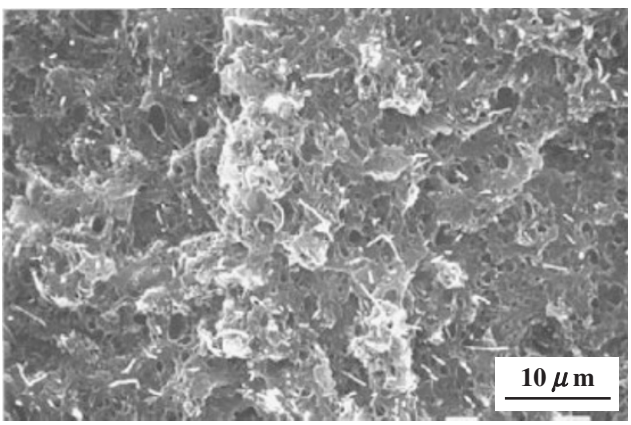

(c) $\mathrm{ABS} / \mathrm{V} 10$

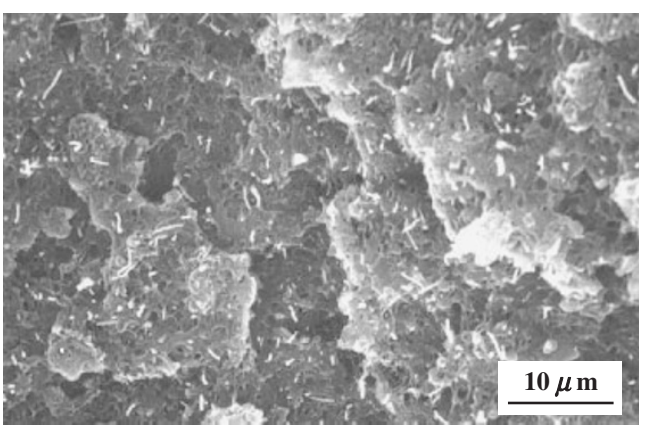

(d) ABS/V15

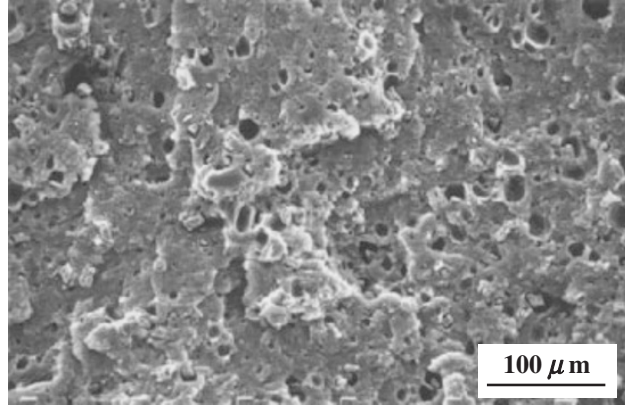

(e) $\mathrm{ABS} / \mathrm{C} 5$

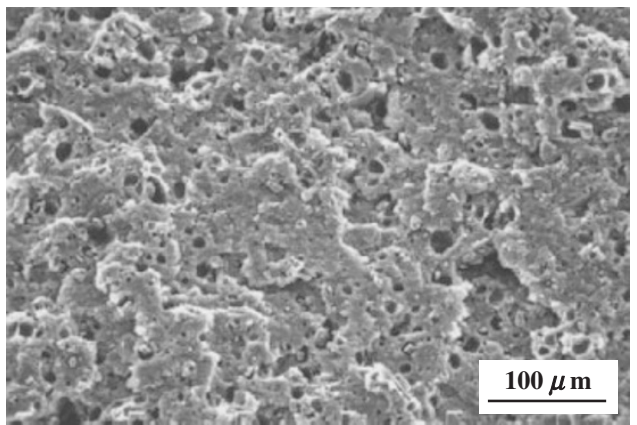

(f) $\mathrm{ABS} / \mathrm{C} 10$

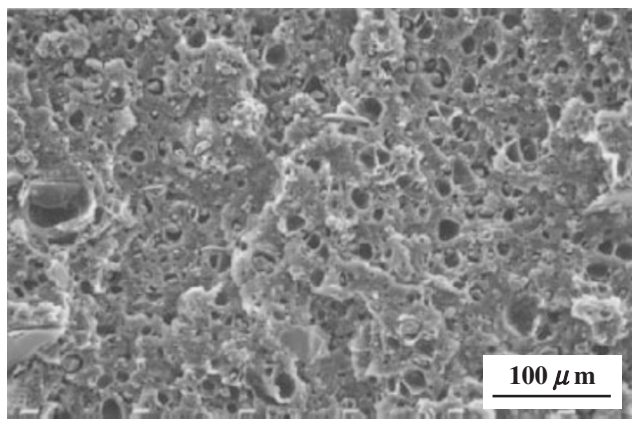

(g) ABS/C15

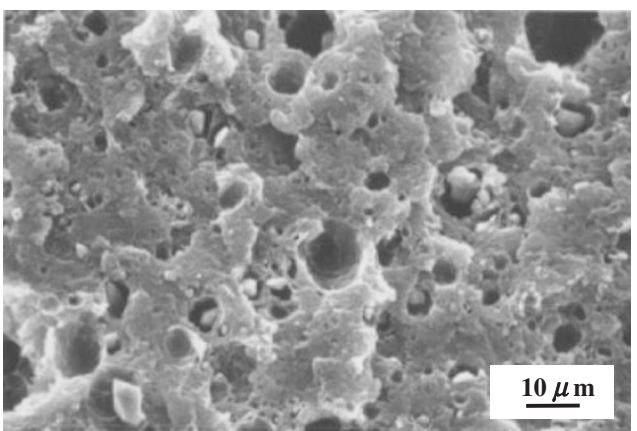

(h) ABS/C10

Figure 3. SEM photographs at cross section of foaming samples.

decreased, and the frequency of $3 \mu \mathrm{m}$ or more increased. By increasing the content of $\mathrm{CaCO}_{3}$, cell diameter increased and the degree of cell distribution became large remarkably.

Figure 5 summarizes, from the quantitative analysis, the effect of filler contents on the foaming cell average diameter and foaming cell density. In the foaming structure of ABS/V15 sample, the foaming cell average diameter became half compared with that of ABS. The foaming cell density of ABS/V15 increased about 6 times, compared with that of ABS. To the contrary, in the foaming structure of ABS/ C15 sample, the foaming cell average diameter became about 10 times larger, compared with that of 


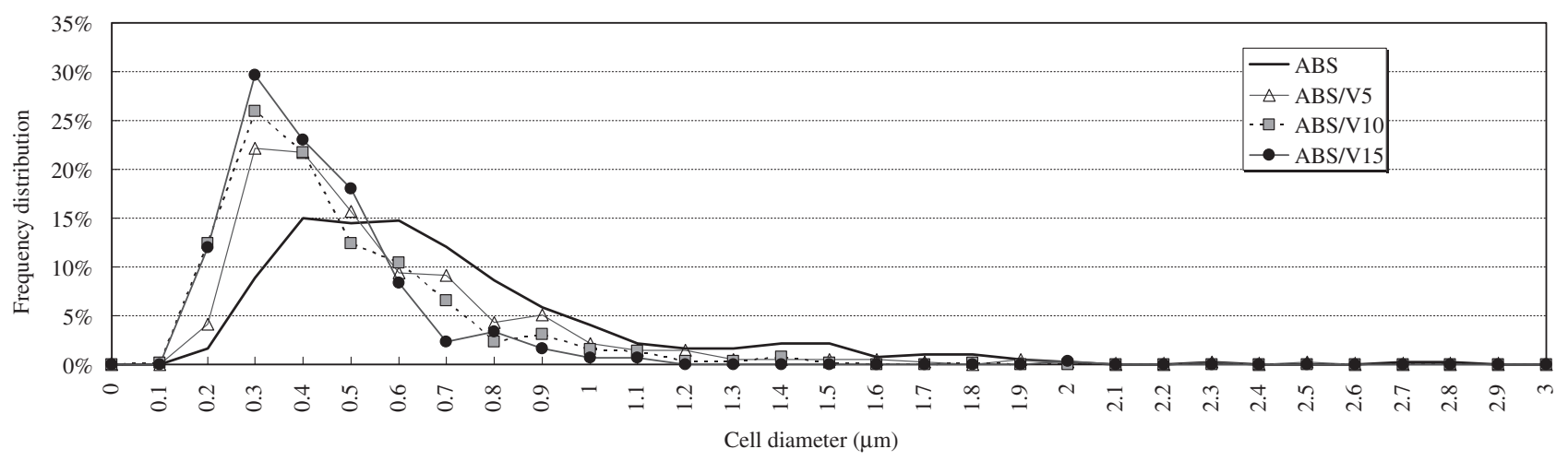

(a)

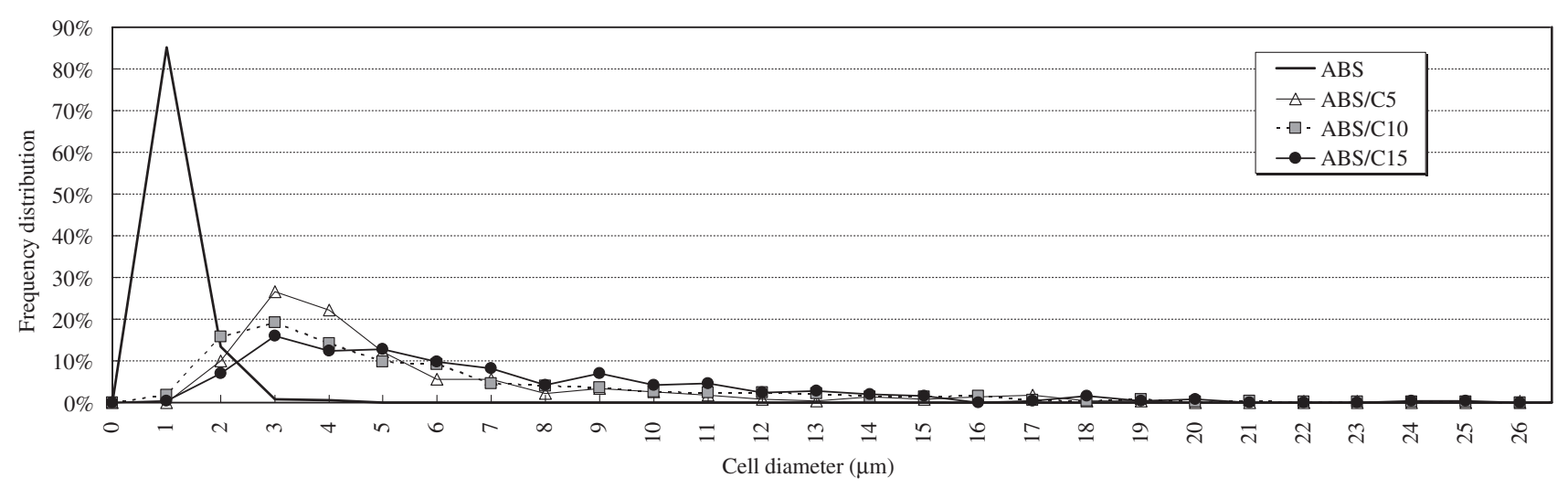

(b)

Figure 4. Frequency distribution of foaming cell diameter for various samples (a) VG-CF content dependence of detailed frequency distribution of foamed cell diameter in $\mathrm{ABS}$ (b) $\mathrm{CaCO}_{3}$ content dependence of detailed frequency distribution of foamed cell diameter in ABS.

ABS. The foaming cell density of ABS/C15 decreased to $1 / 1000$, compared with that of ABS. From the above quantitative result, it was found that the tendency between VG-CF and $\mathrm{CaCO}_{3}$ was completely opposite. Okamoto et al. added the clay in polypropylene, and molded foamed samples having about $80 \%$ of density reduction by batch method. ${ }^{10}$ As a result, it was reported that cell average diameter decreases from $122.1 \mu \mathrm{m}$ to $35.1 \mu \mathrm{m}$ and cell density increases from $4.8 \times 10^{6}\left(\right.$ cells $\left./ \mathrm{cm}^{3}\right)$ to $1.8 \times 10^{8}\left(\right.$ cells $\left./ \mathrm{cm}^{3}\right)$ by adding $7.5 \mathrm{wt} \%$ clay. Similarly, Toyooka et al. added glass beads having the particle diameter of $4 \mu \mathrm{m}$ to cycloolefin copolymer (COC).${ }^{11}$ As a result, it was reported that cell diameter decreases from $9.1 \mu \mathrm{m}$ to $5.1 \mu \mathrm{m}$ and cell density increases from $4.0 \times$ $10^{8}\left(\right.$ cells $\left./ \mathrm{cm}^{3}\right)$ to $2.1 \times 10^{9}\left(\right.$ cells $\left./ \mathrm{cm}^{3}\right)$ by adding $1.0 \mathrm{wt} \%$ glass beads. These results allow us to interpret that cell diameter becomes smaller, when filler having smaller size than that of cell in foamed pure matrix resin is added. It became clear in this study, as shown in Figure 5b, when larger filler than the foaming cell of pure resin was added, the tendency became opposite. The correlation between the type of filler and foaming structure is discussed in the next section.

\section{Foaming Mechanism in ABS}

When ABS resin is foamed, it is thought that the butadiene rubber acts as foaming nucleus. The butadiene rubber is in the rubbery state at a room temperature. Taki et al. reported that the domain resin which is in a rubbery state of polymer blend acts as foaming nucleus in batch foam molding. ${ }^{14}$ Accordingly, it is thought that butadiene rubber in ABS behaved effectively as foaming nucleus.

\section{Mechanism in ABS Including the Fillers}

Figure 6 illustrates the foaming mechanism of various systems based on the SEM observation of cross section with speculation. For filled systems, fillers act as foaming nucleus rather than butadiene particles preferentially. Fillers used in this study are without surface treatment. Such fillers exfoliate with the matrix resin more easily than that with the surface treatment. Therefore, it is thought that carbon dioxide concentrated at the interface accelerated exfoliation easily. In the filler/resin system, it is thought that surface treatment, size and distribution of filler and the viscosity of compound resin, etc have influences on foaming structure. The hypothesis about influence of filler types and content on foaming mechanism is ex- 


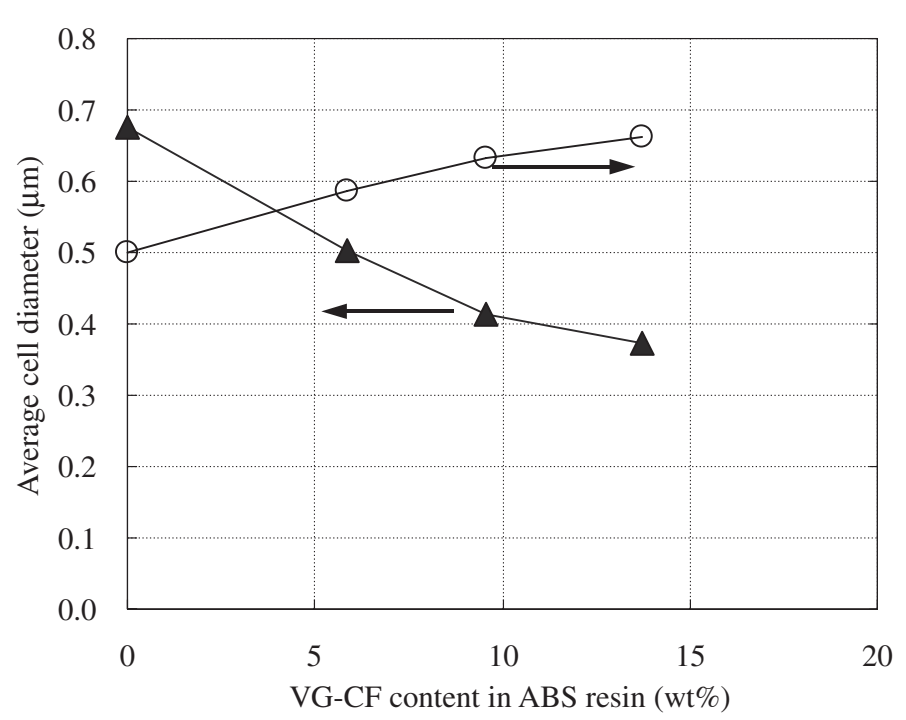

$10^{14}$

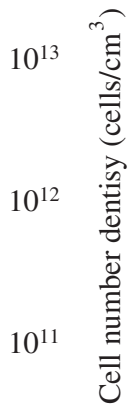

$10^{10}$

(a)

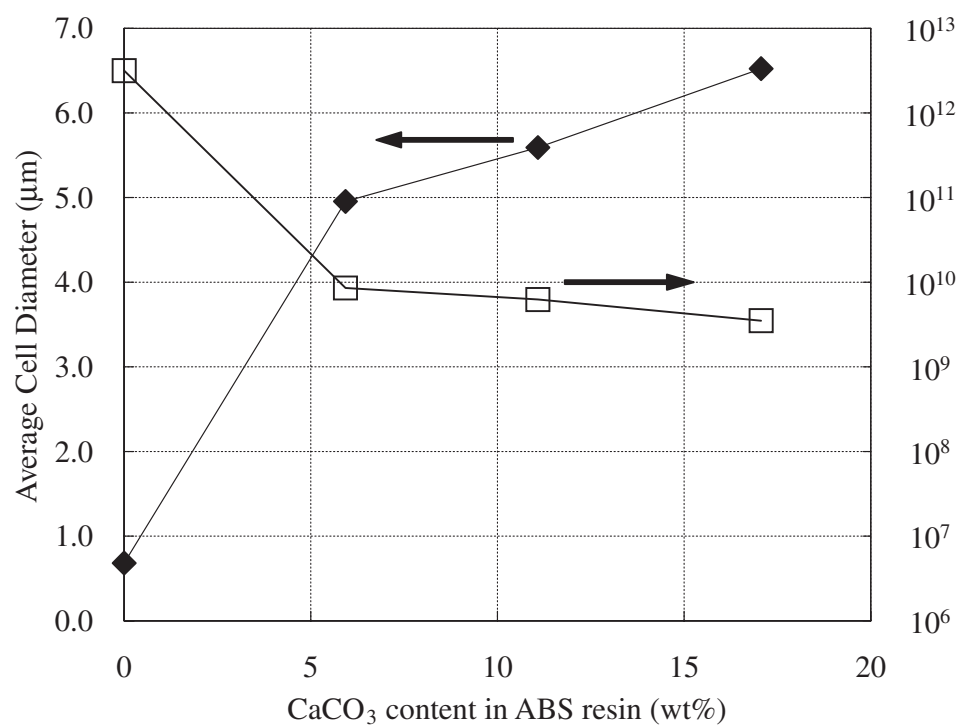

$10^{13}$

$10^{12}$

$10^{11}$

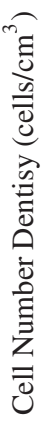

(b)

Figure 5. Filler content dependence of average cell diameter and cell number density (a) VG-CF content dependence of foaming structure in $\mathrm{ABS}$ (b) $\mathrm{CaCO}_{3}$ content dependence of foaming structure in ABS.

plained below.

In the case of fiber type filler like VG-CF, in the initial process of foaming, the ends of the fiber should be operated as foaming nucleus (Figure 6a). When cells grow, foaming cell becomes larger along VG$\mathrm{CF}$ surface. Finally, the foaming cell wraps a fiber (Figure 6b). The fiber diameter of VG-CF is $150 \mathrm{~nm}$ and is smaller than the foaming cell average diameter of foamed ABS. By adding VG-CF, the number of foaming nucleus more microscopic than butadiene rubber increases. Therefore, the foaming cell diameter decreased and the foaming cell density increased.

In the case of $\mathrm{CaCO}_{3}$, two or more foaming nucleus exist around the surface because of rough surface (Figure 6d). In the growth process of cell, a foaming cell wraps one or more $\mathrm{CaCO}_{3}$ particles (Figure 6e).
It was supported by SEM observation. The mean particle diameter of $\mathrm{CaCO}_{3}$ is $1.6 \mu \mathrm{m}$, and is larger than the foaming cell average diameter of pure foamed ABS. Therefore, many big foaming cells were formed by addition of $\mathrm{CaCO}_{3}$. Furthermore, it is thought that union of a foaming cell occurs easily, because the viscosity does not increase by adding $\mathrm{CaCO}_{3}$. Accordingly, by adding $\mathrm{CaCO}_{3}$ to $\mathrm{ABS}$ resin, the foaming cell average diameter increased and the foaming cell density decreased.

\section{Foaming Mechanism with Higher Concentration}

In case of VG-CF system with low concentration, the number of fiber ends used as foaming nucleus is limited. In the growth process of foaming, it seems that the foaming cells along VG-CF become larger 
<smiles>C=C=C</smiles><smiles>C=C</smiles><smiles>C=C</smiles>

a) Cell nucleation process and initial foaming process including low contents of fibers

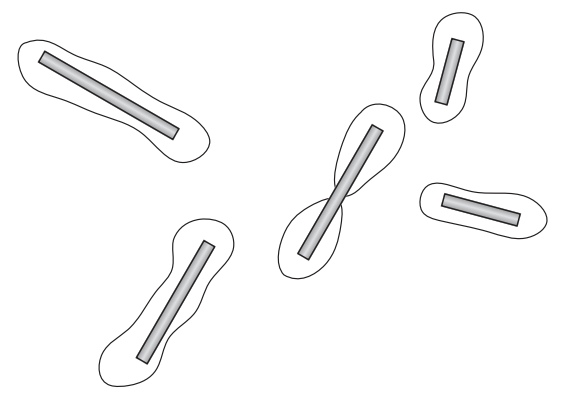

b) Final structure including low contents of fibers

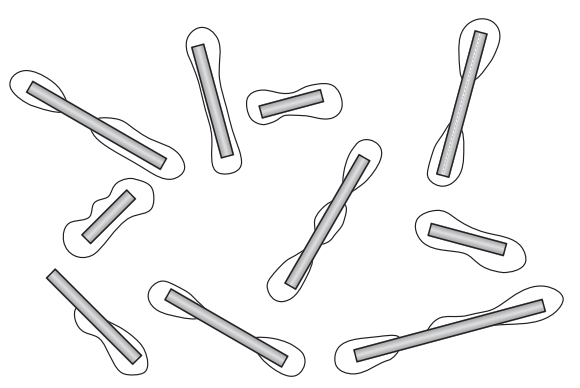

c) Final structure including high contents of fibers

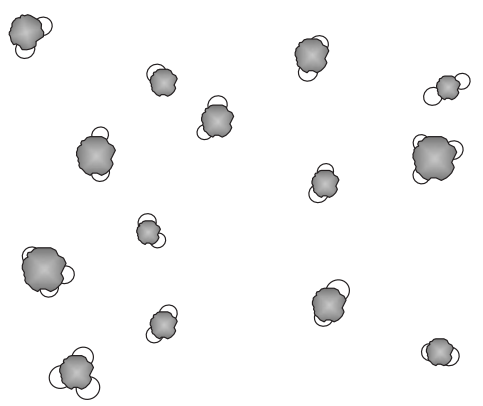

d) Cell nucleation process and initial foaming process including low contents of particles

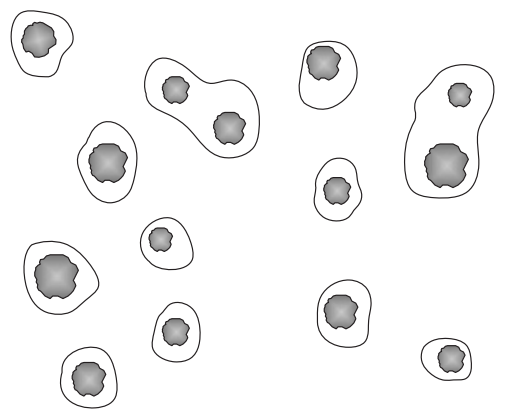

e) Final structure including low contents of particles

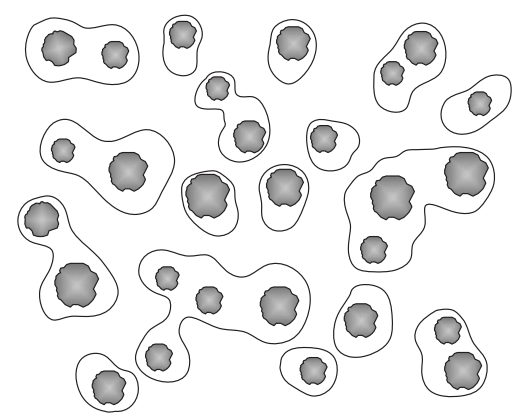

f) Final structure including high contents of particles

Figure 6. Illustrations of hypothetical foaming mechanism in filled ABS.

rather than the generation of new nucleation sites in matrix. According to the reference about the theory of classic nucleation, it is considered that the energy which used of the growth of cell is lower than that of new nucleation generation, supporting the illustration picture of mechanism (Figure 6b). ${ }^{17-19}$ With increasing VG-CF, the number of fiber ends increases. Even in high concentration of VG-CF, it is thought that union of foaming cells does not occur easily by the influence of high viscosity (Figure 6c).

On the other hand, in $\mathrm{CaCO}_{3}$ system, it seems that foaming cell wraps the particle filler easily, because many foaming cells are formed from the surface. Furthermore, two or more cells become united easily, because viscosity does not increase by addition of $\mathrm{CaCO}_{3}$. A big foaming cell is formed of union of these foaming cells. The particle diameter of $\mathrm{CaCO}_{3}$ has wide distribution. A large foaming cell is formed around particle corresponding to its large size. When the content of the particle type filler is high, the distance between particle and particle becomes short. Foaming nucleus increases because the number of particles increases. Accordingly, it is thought that union of a foaming cell occurs further easily. It is thought that a final foaming structure becomes the complicated shape which repeated union. Furthermore, when the content of $\mathrm{CaCO}_{3}$ is high, the number of large $\mathrm{CaCO}_{3}$ increases by having wide distribution. From the above reason, it is thought that foaming cell diameter increases and foaming cell density decreases. Table $\mathrm{V}$ lists the distance of the filler evaluated from the SEM photograph in Figure 3 using image analysis. 


\section{Model Experiments}

In order to examine the above hypothesis, a trace amount of carbon fiber and $\mathrm{CaCO}_{3}$ were compounded to prepare almost transparent $\mathrm{ABS}$ composites as model experiments. Samples were foamed very slightly to observe the nucleation and initial stage of foaming structure of the two systems.

Figure 7 shows optical micrographs of two systems. In the case of carbon fiber (Figure 7a), many foaming cells were generated from nucleation at both fiber ends. Furthermore, the foaming cell which wrapped in carbon fiber completely was also observed. On the other hand, in the case of $\mathrm{CaCO}_{3}$ (Figure 7b), it was observed that foaming cells are generated from three points on the surface with comparatively large

Table V. Distance of fillers calculated from the photographs of the electron microscope in Figure 3

\begin{tabular}{llc}
\hline Sample name & Filler name & $\begin{array}{c}\text { Distance between } \\
\text { the filler surfaces } \\
(\mu \mathrm{m})\end{array}$ \\
\hline ABS/V5 & VG-CF & 1.80 \\
ABS/V10 & VG-CF & 1.26 \\
ABS/V15 & VG-CF & 0.67 \\
ABS/C5 & $\mathrm{CaCO}_{3}$ & 8.41 \\
ABS/C10 & $\mathrm{CaCO}_{3}$ & 5.17 \\
ABS/C15 & $\mathrm{CaCO}_{3}$ & 4.08 \\
\hline
\end{tabular}

size. Many foaming cells which wrapped in $\mathrm{CaCO}_{3}$ were observed. The foaming cell on the left-hand side in the photograph was the same shape as $\mathrm{CaCO}_{3}$. From the above result, it was suggested that the foaming cell grew along the filler surface. These evidences of model experiments supported the hypothetical explanation described.

\section{CONCLUSIONS}

In this study, we have prepared vapor grown carbon fiber/ABS and the calcium carbonate/ABS systems for characterization in microcellular foaming. The influence about the content of two types of fillers on the foaming structure was examined. As a result, the following things became clear.

(1) When vapor grown carbon fiber (averaged fiber diameter $=150 \mathrm{~nm}$ ) was added to ABS, the foaming cell average diameter decreased, and the foaming cell density increased with the increase of filler content.

(2) When calcium carbonate (averaged particle diameter $=1.8 \mu \mathrm{m}$ ) was added to ABS, the foaming cell average diameter increased, and the foaming cell density decreased with the increase of filler content.

(3) In model experiments to observe the nucleation and initial foaming stage for fiber and particle type fillers, a trace amount of carbon fiber (fiber diameter $=7 \mu \mathrm{m}$ ) and calcium carbonate (mean particle

Cell nucleation and initial foaming process
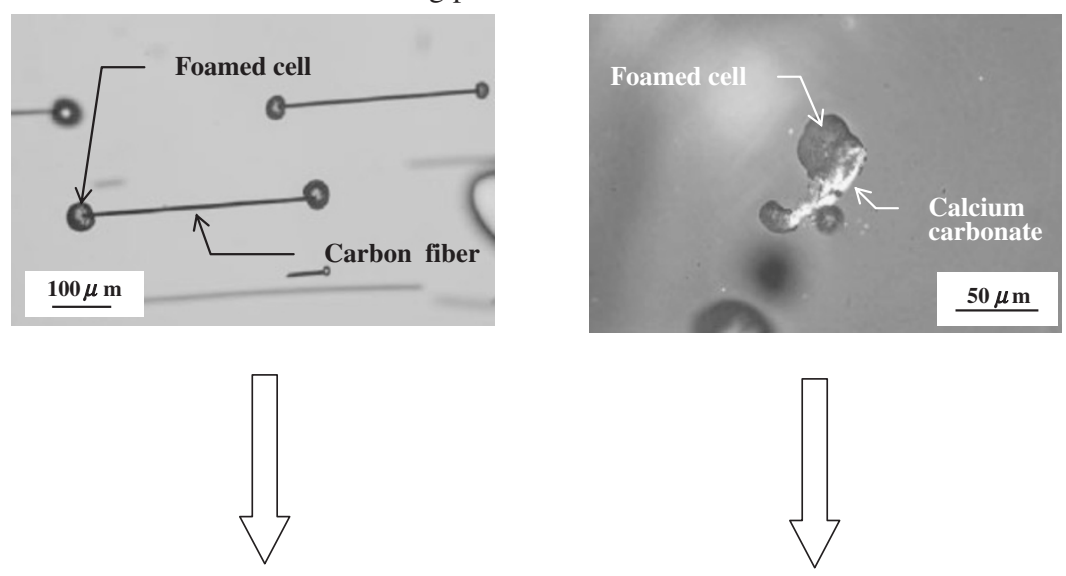

Final foaming structure
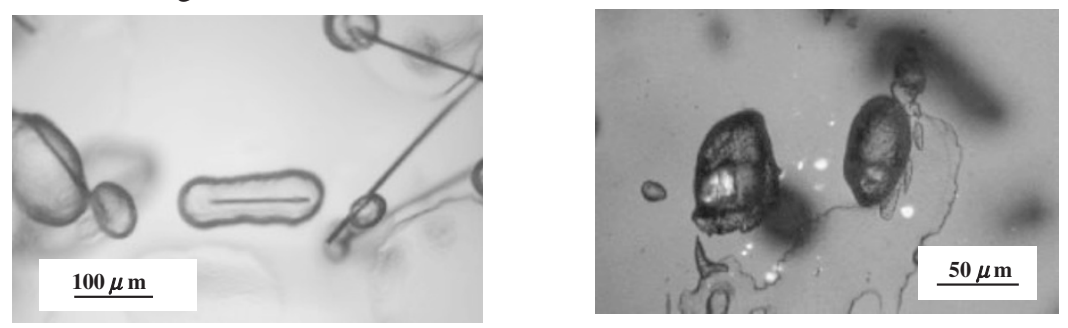

a) Fiber

b) Particle

Figure 7. Photographs about foaming of transparent ABS in fiber and particle filler. 
diameter $=50 \mu \mathrm{m}$ ) were compounded to transparent ABS resin. The behavior of foaming cell formation was observed using this compound sample. Optical microscope observation demonstrated that foaming cells were generated at the both ends of fiber for fiber type filler. In the case of the particle type filler, foaming cells were generated from several points on the surface. For both fillers, foaming cells grow and wrap fillers.

(4) When fiber type filler is added to ABS resin, the union of foaming cells does not occur, because the viscosity of compound resin increases. While particle type filler, the union of the foaming cell occurs easily, because of relatively low the viscosity.

Acknowledgment. This study was financially supported by Fukushima technology centre.

\section{REFERENCES}

1. M. Simbo, D. F. Baldwin, and N. P. Suh, Seikei Kakou, 6, 863 (1994).

2. Y. Sato, Seikei Kakou, 13, 71 (2001).

3. A. Kabumoto, Plasticage, Mar, 83 (2002).
4. M. Ohshima, Seikei Kakou, 15, 372 (2003).

5. H. Kawashima and M. Simbo, Seikei Kakou, 15, 632 (2003).

6. M. Ohshima, Seikei Kakou, 12, 424 (2000).

7. F. Tsuda, Seikei Kakou, 13, 83 (2001).

8. Y. Otsuki, T. Kanai, K. Taki, and M. Ohshima, Seikei Kakou, 15, 638 (2003).

9. T. Isaki, Seikei Kakou, 12, 680 (2000).

10. P. H. Nam, P. Maiti, M. Okamoto, and T. Kotaka, Poly. Eng. Sci., 42, 1907 (2002).

11. D. Toyooka, H. Kawashima, M. Simbo, and T. Izumitani, Seikei Kakou Symposium 2002, Technical papers, E111 (2002).

12. H. E. Naguib, C. B. Park, P. C. Lee, and N. Reichelt, SPE, ANTEC, Technical Papers, 796 (2003).

13. C. B. Park, X. Xu, and D. Xu, Polymer-Supercritial Fluid Systems and Foams, Technical Papers, 52 (2003).

14. K. Taki, K. Nitta, S. Kihara, and M. Ohshim, J. Appl. Polym. Sci., 97, 1899 (2005).

15. Y. Nagao, T. Morita, and M. Takeuchi, Plasticage, (5), (2004).

16. E. Sato, T. Takahashi, and K. Koyama, Kobunshi Ronbunshu, 61, 144 (2004).

17. J. S. Colton and N. P. Suh, Polym. Eng. Sci., 27, 485 (1987).

18. J. S. Colton and N. P. Suh, Polym. Eng. Sci., 27, 493 (1987).

19. J. S. Colton and N. P. Suh, Polym. Eng. Sci., 27, 500 (1987). 